\title{
Renewable hydrogen as an energy storage solution
}

\author{
Barbara Widera ${ }^{1, *}$ \\ ${ }^{1}$ Wrocław University of Science and Technology, Faculty of Architecture, ul. B. Prusa 53/55, \\ 50-317 Wrocław, Poland
}

\begin{abstract}
The paper will discuss the potential of renewable hydrogen as an energy storage medium for the decarbonisation of multiple sectors and for the energy system security. The author will particularly focus on the applications related to the building industry with perspectives to be further developed. The paper will cover the most up-to-date initiatives addressing the combination of hydrogen production based on water electrolysis and solar energy methods with the possibility of hydrogen implementations for energy storage, transportation and stationary applications such as combined heat and power (CHP) plants or fuel cell electric generators. The opportunity to reach improved efficiency and cost-effectiveness in the energy transition will be presented on the example of the two selected case studies: the world's first full-scale wind power and hydrogen plant and the most up-to-date on-going project chosen by Fuel Cells and Hydrogen Joint Undertaking. They will be analysed in purpose to draw the conclusions regarding the options and limitations of the actual renewable hydrogen based energy storage systems tested in the real life situation. The second aim of the paper is to formulate the recommendations for the further action in this field, including the reduction of some non-technological barriers.
\end{abstract}

\section{Introduction}

The development of sustainable energy technologies is a necessary part of tackling climate change action aimed at holding the increase in the global average temperature to well below $2{ }^{\circ} \mathrm{C}$ above pre-industrial levels and pursuing efforts to limit the temperature increase to $1.5^{\circ} \mathrm{C}$ above pre-industrial levels, as stated in the Paris Agreement [1]. Especially renewable hydrogen has a great potential for the decarbonisation of multiple sectors as well as for the energy system security. The role of hydrogen as a "promising link between the electricity, industry and mobility sectors, opening new windows of opportunity in energy flexibility, availability, security, as well as improved efficiency and cost-effectiveness in the energy transition" was emphasised by the Hydrogen Initiative [2] signed by 25 EU countries in 2018. The same declaration underlined the importance of raising public awareness and acceptance for hydrogen technologies.

In the process of traditional production, hydrogen has been obtained from fossil sources by steam methane reforming of natural gas. Nowadays, the sustainable production method,

\footnotetext{
*Corresponding author: barbara.widera@pwr.edu.pl
} 
strongly supported by Fuel Cells and Hydrogen Joint Undertaking (FCH JU), is based on water electrolysis using renewable electricity. Most of attention is given to research and development of electrolyser technology and application projects, aiming to increase the energy efficiency and cost effectiveness of electrolytic hydrogen production from renewable sources. Parallelly, alternative green hydrogen generation technologies are explored, including:

- biomass pyrolysis and gasification,

- raw biomass reforming,

- thermochemical water splitting based on renewable high temperature heat,

- photo catalysis,

- fermentation and photofermentation,

- supercritical water gasification of biomass,

- photo-biological water splitting including algae bioreactors and photosynthetic microbes,

- electrohydrogenesis (biocatalysed electrolysis),

- plasma-supported gasification,

- plasma-based carbon black process.

When taking water electrolysis as a benchmark, the cost of hydrogen production using the biomass-based methods as well as water splitting and photo-catalysis are similar. Only the dark fermentation of wet biomass combined with anaerobic digestion represents significantly higher costs. The same regards the issue of primary energy use [3]. However, in terms of greenhouse gas emissions the biomass based methods generate significant emission levels when compared to water electrolysis and only the hydrogen production using the solar energy offers similar GHG reduction potential to the water electrolysis [3]. Consequently, the sites that offer the opportunity to combine the hydrogen production using electrolysis and solar energy methods with the possibility of hydrogen implementations for energy storage, transportation and stationary applications, such as combined heat and power (CHP) plants or fuel cell electric generators, are particularly promising and should be selected for the pilot projects.

Hydrogen can be used both for short-term and long-term storage of renewable energy. The ongoing research activities are focused on biological conversion of hydrogen to methane and other hydrocarbons. Thus, with the adequate fuelling infrastructure, hydrogen can be successfully applied in transport and mobility, being introduced for fuel cell electric vehicles. The analysed case studies, i.e. projects combining the wind power and hydrogen plant, prove that the green hydrogen from electrolysis can improve the efficient use of variable and intermittent renewable energy for diverse purposes. The most promising integrated model of hydrogen production, storage, transportation and utilisation for low carbon heat, power and transport has been further explored within the paper.

\section{Analysis of pilot case studies}

The analysis of case studies presented in this part of the paper is based on the notion of green hydrogen in the understanding of $\mathrm{FCH}$ JU which means that within the whole hydrogen production process solely renewable energy input is used. In the case of green hydrogen from water electrolysis, the electricity is exclusively renewable [3]. According to the EU Renewable Energy Directive (RED) it means "from renewable non-fossil sources, namely wind, solar, aerothermal, geothermal, hydrothermal and ocean energy, hydropower, biomass, landfill gas, sewage treatment plant gas and biogases" [4]. $\mathrm{CO}_{2}$-free electricity such as nuclear energy was excluded from this research. 
Nowadays, in about 50 pilot and demonstration plants worldwide, electrolysers have been tested for integrated generation of renewable electricity and the alternative energy carriers production (hydrogen or synthetic methane). In recent projects $1 \mathrm{MW}$ electrolysers or larger are used [5]. However, the cases where hydrogen from electrolysis is used in energy applications, including energy storage or sustainable transport, are rare and limited to particular locations. This is often related to policy regulations, which usually have to be adjusted to the specific demands of hydrogen usage. The pilot projects strive for better understanding of the potential and challenges of the hydrogen technology, electrolyser operation, plant siting, permitting, and regulations, as well as with power and gas grid connections [6].

The two case studies were selected for the analysis. The selection was based on the particular role of these projects in the development of renewable hydrogen production and storage systems, designed to provide the clean energy for the buildings. In both analysed case studies hydrogen is produced in the proximity of the point of use.

The first pilot is positioned in Norway, at Utsira island. It was selected for this research as the world's first full-scale combined wind power and hydrogen plant. The second case study is an ongoing project launched in United Kingdom, namely on Shapinsay and Eday, the two islands on Orkney Archipelago. This project was chosen as the first complex demonstration plant based on integrated model of hydrogen production, storage, transportation and utilisation. Both projects offer the implementation in the building industry (heat and power supply). The purpose of analysis is to draw conclusions related to the opportunities and limits of the actual renewable hydrogen storage systems tested in the real life situation.

\subsection{The world's first full-scale combined wind power and hydrogen plant}

The world's first full-scale combined wind power and hydrogen plant has been located at Utsira, the island situated in a distance of approximately $20 \mathrm{~km}$ from the west shore of Haugesund, Norway. Utsira has about 200 inhabitants and is connected to the mainland by ferry. Due to the severe weather conditions transportation is often disturbed. This makes the fossil fuel supplies from the mainland expensive and uncertain. On the other hand the strong winds, typical for the island, are favourable for the wind energy production. The Utsira Wind Power and Hydrogen Plant was operated in the period 2004-2008. The venture was financed by Statoil ASA and operated together with wind turbine manufacturer Enercon $\mathrm{GmbH}$. The purpose of the project was to demonstrate hydrogen production through wind electrolysis and consequently to prove the ability to provide safe, continuous, and efficient energy supply to distant areas by developing and testing a full-scale, wind-hydrogen energy system [7]. Furthermore, the authors planned to reduce costs and optimize the technical solutions based on the results of the project, so that in the final effect would be the commercialization of the production method.

During the test period ten households located at Utsira were entirely supplied by the energy generated from two wind turbines Enercon E40, installed also at Utsira. The plant was operated from the control centre situated on the mainland. The back-up power was available from the continent via the existing 1 MW subsea cable. Each turbine had a capacity of $600 \mathrm{kWh}$. One of the turbines would produce electricity directly for the external grid and the other was connected to the autonomous system through a $300 \mathrm{~kW}$ onedirectional inverter. The energy surplus above $300 \mathrm{~kW}$ from the autonomous system could be redirected to the local grid. The plant was in continuous operation for the whole four years and for more than half the time it worked in stand-alone mode. 
For the grid stabilization in the autonomous system a $5 \mathrm{kWh}$ flywheel was installed to provide frequency control, as well as a $100 \mathrm{kVA}$ master synchronous machine for voltage control and a Ni-Cd battery for redundancy (Fig. 1).

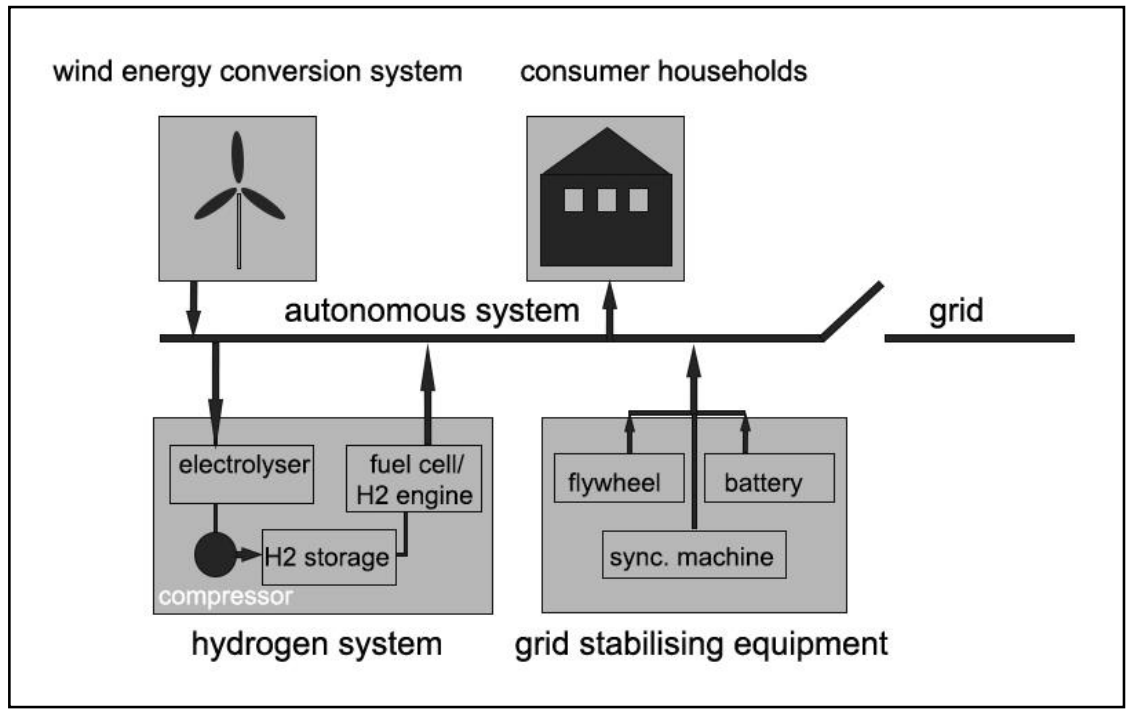

Fig. 1. Utsira wind/hydrogen demonstration plant system schedule, drawing based on Harg [9].

Hydrogen Technologies electrolyser $\left(10 \mathrm{Nm}^{3} / \mathrm{h}, 50 \mathrm{~kW}\right)$ was switched on when the power production from the wind turbines would exceed the demands of the households. In practice this means that hydrogen was produced on windy days. Then it was compressed with the Hofer compressor $(5 \mathrm{~kW})$ and stored in a 200 bar tank (2400 $\mathrm{Nm}^{3}$ capacity). During weather conditions preventing the operation of wind turbines continuous power supply to the houses was possible with the $55 \mathrm{~kW}$ MAN hydrogen internal combustion engine and a $10 \mathrm{~kW}$ IRD fuel cell that would use the stored hydrogen to produce electricity. In such cases the electrolyser was switched off and the hydrogen engine was switched on. The flywheel was charged during the short term increases in power to cover short term decreases in power by stored energy (Fig. 2). In the excess power prolonged period, when the battery was fully charged, the hydrogen engine would be switched off and the electrolyser would be switched on again.

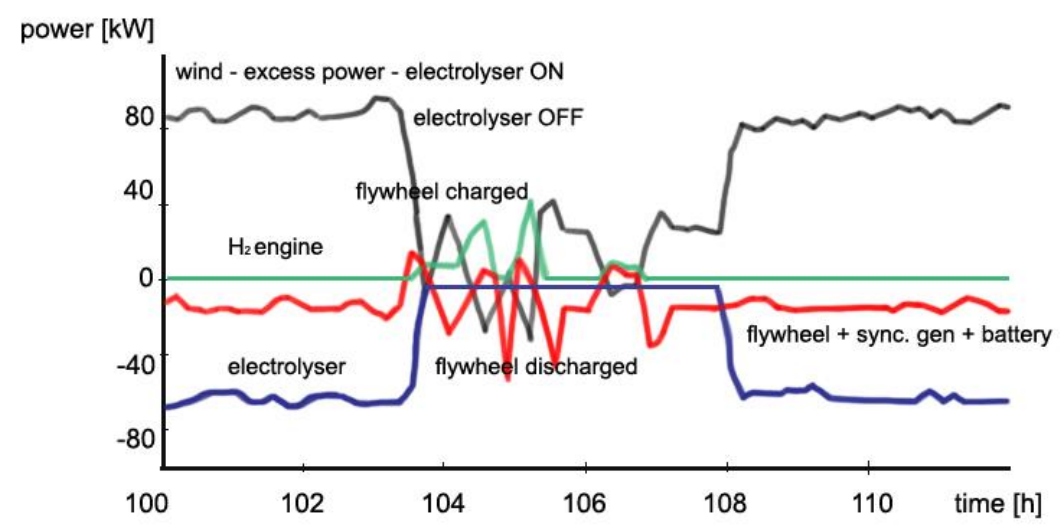

Fig. 2. Utsira demonstration plant operational data, March 2007, drawing based on Ulleberg et al. [8]. 


\subsection{Lessons from the Utsira project}

Utsira Wind Power and Hydrogen Plant successfully demonstrated that the combination of wind power energy production with hydrogen electrolyser and using hydrogen as the energy storage medium is possible and can provide reliable energy supply, especially for the remote communities. The power quality was good and the project resulted with the high level of customers' satisfaction. Nevertheless, some technical issues appeared. In particular the low durability of the fuel cell (less than 100 hours) was disappointing. Another disadvantage was the difficulty to predict the electrolyser lifetime. Some other problems were related to the coolant fluid leaking and the damage to the voltage monitoring system during assembly. Frequent false grid failure alarms were disquieting as the plant was remotely operated [7]. The hydrogen engine used to work well for 3 years and after that its pistons have been damaged. In selected analysed periods (e.g. 1-30 March 2007) the stand-alone operation achieved $65 \%$ of time [8]. However, during the whole operation period the wind energy utilization reached only $20 \%$ and the project leaders concluded that there is a need to develop high-performance electrolyser (more efficient, with small footprint) and to improve the hydrogen-electricity conversion efficiency [9]. Another suggestion would address multiple renewable energy sources (e.g. wind, solar, bioenergy) that should be included in future projects [7].

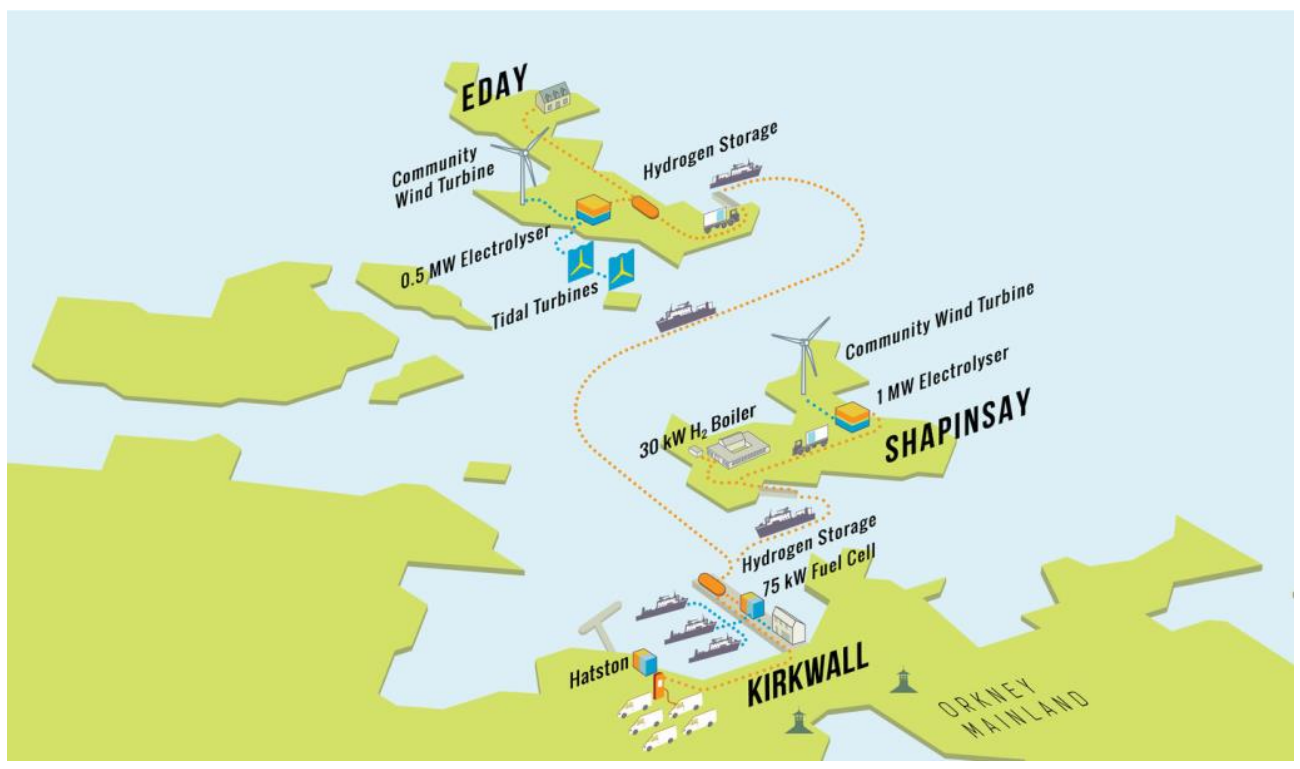

Fig. 3. The graphic presentation of the BIG HIT Building Innovative Green Hydrogen Systems in an Isolated Territory: a Pilot for Europe [10].

\subsection{The world leading pilot and demonstration project based on integrated model of hydrogen production, storage, transportation and utilisation}

The use of hydrogen for energy storage is still the subject of research and development and the interest in this topic is constantly growing. Among multiple proposals submitted under Horizon 2020, the project BIG HIT Building Innovative Green Hydrogen Systems in an Isolated Territory: a Pilot for Europe was selected by the FCH JU and received funding as the only hydrogen project of its kind. As the world leading pilot and demonstration project 
BIG HIT aims to put in place a fully integrated model of hydrogen production, storage, transportation and utilisation for low carbon heat, power and transport (Fig. 3).

The foundations for this project have been established by the Orkney Surf ' $n$ ' Turf program that initiated hydrogen production using wind and tidal energy on the Eday and Shapinsay, the two islands of the Orkney archipelago. The EMEC test site has 8 tidal test berths at depths from 12 to 50 meters, in an area of 2 by 4 kilometres, situated west of the island of Eday where high velocity marine currents can reach even $4 \mathrm{~m} / \mathrm{sec}$. The tidal test side is connected to the substation at Caldale in Eday with $11 \mathrm{kV}$ sub-sea cables. The substation is equipped with the main switchgear and back-up generator. The role of the station is to control the supply from tidal devices and to provide connection to the grid.

The official inauguration of BIG HIT took place in May 2018. The project has 12 participants from $6 \mathrm{EU}$ countries and the concept combines energy from communityowned Enercon E44 wind turbines, $900 \mathrm{~kW}$ each, located Shapinsay and Eday, with hydrogen production and storage.

Renewable electricity generated on the two islands is used to produce low carbon hydrogen and oxygen with the two state-of-the-art ITM Power proton exchange membrane (PEM) electrolysers: one with the capacity of $1 \mathrm{MW}$ and the other of $0.5 \mathrm{MW}$. Both electrolysers are characterized by compact size, rapid response, high operating efficiency and high pressure output capability (Fig. 4). They will use otherwise curtailed capacity to produce about 50 tonnes of ultra-pure hydrogen each year [10].

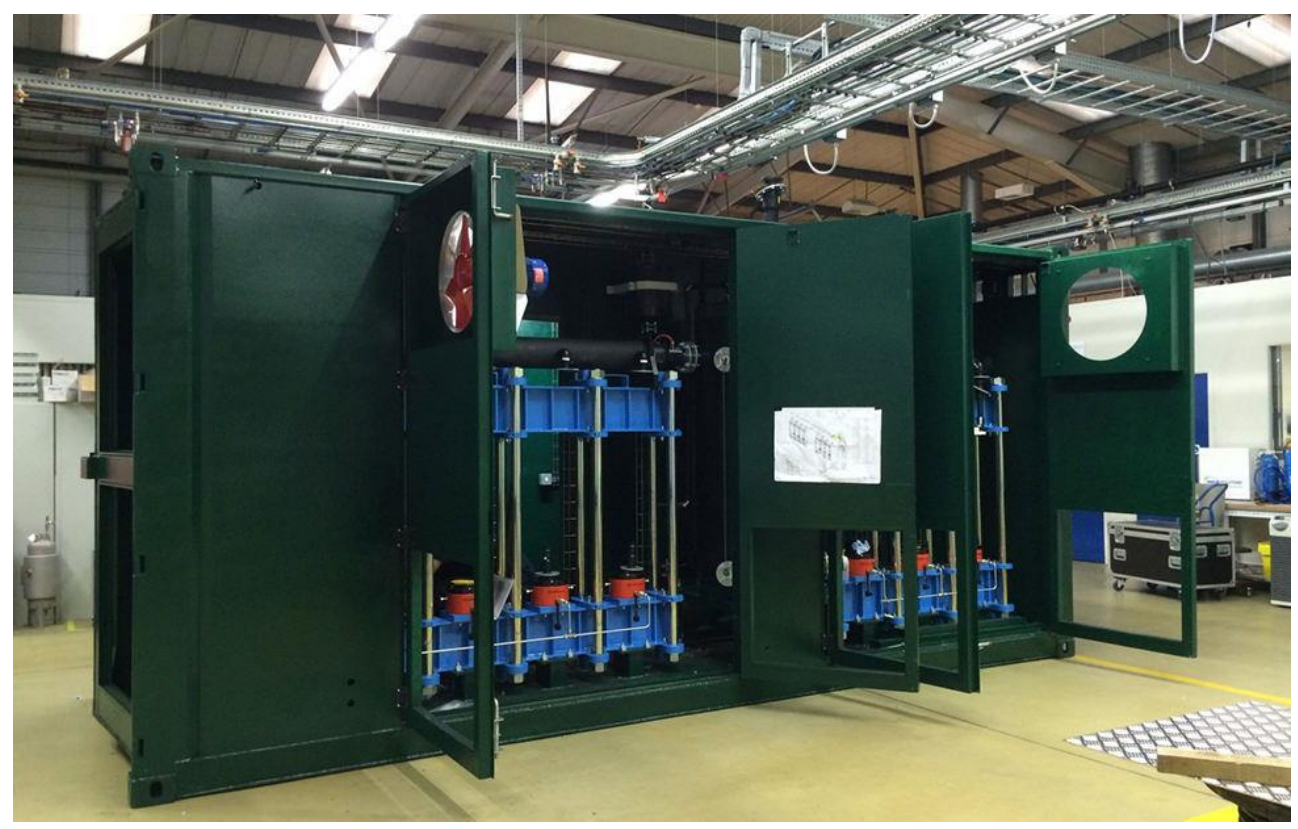

Fig. 4. Proton exchange membrane (PEM) electrolyser by ITM Power installed on Orkney [10].

The hydrogen is used as an energy storage medium. When needed it can be converted to electricity and heat. Hydrogen is stored as high pressure gas in the tube trailers. As regular tube trailers are too heavy, Calvera produced a new tube model, that may be safely transported on Orkney roads and by the sea. Especially for marine transportation of hydrogen the rigorous safety tests were required [10]. 
Some hydrogen produced by the two electrolysers may be used to heat local buildings but most of it will be transported in 5 tube-trailers to Kirkwall. There, a $75 \mathrm{KW}$ hydrogen fuel cell installed in 2017 as part of the Surf ' $n$ ' Turf project, uses the hydrogen and oxygen for the electricity production. The 3 Proton Motor PM 400 fuel cell stacks, with nominal electrical power of $4.0-30.0 \mathrm{~kW}$ each, are suitable for maritime stationary applications. The electricity is used by the local premises and vessels in the harbour while the heat, as a by-product of the chemical reaction in the fuel cell, is send to the nearby buildings. Two hydrogen-powered boilers will provide zero carbon heat for the local school [11]. The hydrogen refuelling station has been open in Kirkwall and delivers fuel for the 5 zero-emission hydrogen vehicles for Orkney Islands Council. This fleet will be further enlarged to 10 hybrid (combined electric and hydrogen) Symbio vans based on the Renault Kangoo ZE Maxi with a $22 \mathrm{kWh}$ Li-Ion battery and fitted with a $5 \mathrm{~kW}$ hydrogen fuel cell range extender. The operational range of these vans will be doubled due to the extender system. Finally, there will be no impact from using the cabin heating on the range [10].

\section{Conclusions}

The analysis of the two case studies presented above allows to conclude that the use of renewable hydrogen produced in efficient PEM electrolysers, powered by the wind and tidal (and in some other cases also solar) energy, as an energy storage medium represents substantial environmental and economic advantages. In particular it may significantly contribute to more stable, efficient and sustainable energy systems for isolated territories [12]. However, to benefit from the hydrogen potential, several conditions should be met. The hydrogen production must be based on local renewable energy generation and electrolysers should be located in proximity of power plants, preferably in the harbour area to have an easy access to the sea water as well as to the marine and land transportation. The selected sites should offer the opportunities for the hydrogen implementations for energy storage, transportation and stationary applications, including hydrogen refuelling station for vehicles and sea vessels. Combined CHP plants or fuel cell electric generators are strongly recommended. The potential of the hydrogen fuel cells should be further explored for energy conversion and zero emission power generation. Appropriate fuel cells offer high level of efficiency in the field of fuel utilisation as well as environmentally safe operation, with pure water as the end product of the electrochemical conversion process.

Analysed case studies confirmed the technology readiness and technical feasibility for energy generation and storage systems based on renewable hydrogen. Technical problems reported during the Utsira project (and other pilots and demonstrations) were overcome, so that the system efficiency was significantly improved, including also the issue of cost-effectiveness. High-performance electrolysers have already increased the productivity of hydrogen-electricity conversion. The combination of wind and tidal renewable energy brought about positive results. Both described projects prioritised the safety, organized good information campaigns and received tremendous support from local communities and authorities. Such approach is necessary for tacking the non-technological barriers and for creating positive ambiance towards using renewable hydrogen as an environmentally safe energy storage solution.

\section{References}

1. United Nations Framework Convention on Climate Change, Paris Agreement, United Nations (2015) 
2. E. Köstinger, The Hydrogen Initiative (Declaration of Linz high-level energy conference, Federal Ministry Republic of Austria Sustainability and Tourism, 17-18 Sept. 2018, Linz (2018) https://www.eu2018.at/latest-news/news/09-18Informal-meeting-of-energy-ministers.html, access 3 Apr 2019)

3. U. Albrecht, M. Altmann, F. Barth, U. Bünger, D. Fraile, J. C. Lanoix, E. Pschorr-Schoberer, W. Vanhoudt, W. Weindorf, M. Zerta, W. Zittel, Study on Hydrogen from Renewable Resources in the EU, Final Report (Brussels, 2015)

4. European Parliament, Council of the European Union, Directive 2009/28/EC of the European Parliament and of the Council of 23 April 2009 on the promotion of the use of energy from renewable sources and amending and subsequently repealing Directives 2001/77/EC and 2003/30/EC, Brussels (2009)

5. G. Gahleitner, International Journal of Hydrogen Energy 38, 5, 2039-2061 (2013)

6. L. Bertuccioli, A. Chan, D. Hart, F. Lehner, B. Madden, E. Standen, Development of Water Electrolysis in the European Union, Final Report (Fuel Cells and Hydrogen Joint Undertaking, Brussels, 2014)

7. IPHE, Utsira Wind Power and Hydrogen Plant (2011) http://www.statoil.com/en/NewsAndMedia/Multimedia/features/Pages/HydrogenSociet y.aspx [access 11.11.2017]

8. Ø. Ulleberg, T. Nakkenb, A. Etéc, International Journal of Hydrogen Energy 35, 5, 1841-1852 (2010)

9. K. Harg, Utsira - demonstrating the hydrogen society on renewable terms (2005) [access 6.04.2018] http://www.hydrogenambassadors.com/hm05/conference/utsira.pdf

10. Fundación Hidrógeno Aragón, Building Innovative Green Hydrogen Systems on Isolated Territories, https://www.bighit.eu/about [access 9.04.2019]

11. K. Olsen, Hydrogen and Fuel Cell Activities in Scotland \& the Orkney Islands, Highlights \& Next Steps, CFA-ITM Power, Scottish Fuel Cell and Hydrogen Association, 2016. [access 26.10.2016] http://www.scandinavianhydrogen.org/wpcontent/uploads/2016/11/1_Kristoffer-Olsen.pdf

12. B. Widera, Innovative RES Solutions for Isolated Territories: Hydrogen as a Storage Medium Integrated with Renewable Energy Sources (In: E. Ng, S. Fong, C. Ren (ed.), PLEA 2018: Smart and Healthy Within the Two-Degree Limit: Proceedings of the $34^{\text {th }}$ International Conference on Passive and Low Energy Architecture 1, Hong Kong 2018) 